\title{
Quality of Work Life and Its Effect Upon Entrepreneurial Management
}

\author{
${ }^{1}$ Chandrani Bojar \\ ${ }^{1}$ Faculty of Management, Public university in Warsaw, 00-927 Warszawa, Poland. \\ 1bojarc@wz.uw.edu.pl
}

\author{
Article Info \\ Journal of Journal of Enterprise and Business Intelligence (http://anapub.co.ke/journals/jebi/jebi.html) \\ Doi: https://doi.org/10.53759/5181/JEBI202101010 \\ Received 25 September 2020; Revised form 20 October 2020; Accepted 26 December 2020. \\ Available online 05 April 2021. \\ (C)2021 Published by AnaPub Publications.
}

\begin{abstract}
The study aims to reveal quality of work life and its effect upon entrepreneurial thinking, and it results from a problem that most service organizations suffer from, poor working environment conditions for individuals, which affected the efficiency of their performance when demonstrating their abilities and creative ideas during their work. So, the study community is the Ministry of Labor and Social Affairs with a sample of (214) individuals out of the total community of officials in the middle management of the bodies and departments of the ministry with a number (478). The questionnaire was used as a main tool, visits and personal interviews, and the analytical descriptive approach was adopted using the statistical measures Cronbach's Alpha, weighted arithmetic means, standard deviations, (Z-TEST) and (F-TEST), the relative importance and simple and multiple linear regression analysis, stepwise with the help of AMOS25, Excel v.10 and SPSS v.25 programs. The most prominent conclusions are the presence of a top correlation between the quality of work life and entrepreneurial thinking at a significant level, the high correlation with the entrepreneurial thinking is the organization climate , and the lower correlation with the entrepreneurial thinking are fees and bonuses, as well as the presence of a noticeable effect on the quality of life with its six dimensions together in the entrepreneurial thinking of the Ministry with a factor of determining its rate $(74.4 \%)$ at a moral level. By diagnosing the most influential dimensions in entrepreneurial thinking by analyzing the gradual linear regression to indicate the organizational climate, training and development of employees, health conditions and occupational keep, and opportunities for Upgrading and career advancement, Collectively in entrepreneurial thinking with a factor of determination of $(72.4 \%)$ at the level of significance less than the level of morale and exclude wages, bonuses and material work environment that is less influenced in the entrepreneurial thinking.
\end{abstract}

Keywords - Quality of Work Life; Entrepreneurial Thinking; Organizational Climate; Proactivity; The Quality of Work Life (QWL).

\section{INTRODUCTION}

A review of the independent variable for quality of working life

The Quality of Work Life (QWL) is one of the vital topics, especially the attention given to its subject by psychologists in the field of work, and researchers with a specialization in management, so our world today is the world of our organizations and the main pillar in managing these organizations is the availability of a better professional life for workers that generate a motivated workforce by providing necessary and good services and effective contribution to achieving the goals. The study [12] came out, and the problem was defined by explaining the role of (QWL) in changing the negative behavior \& improving the performance of the organization and enabling its administrative leadership to make constructive decisions with high quality; the study aimed to know the nature of the relationship and the effect between $(\mathrm{QWL})$, quality of taking-decision, identification of individual differences between among the personnel of workers, with a sample of (58) employees at the University of Sulaymaniyah in Kurdistan, Iraq. The most prominent results are the presence of a moral correlation and overall level between (QWL) \& quality of decision-making amounted to (0.778), as well as a significant impact on the (QWL) in the quality of decision-making by (77.8\%), which is a high percentage that explains the influential relationship of the work life quality variable in the decision-making quality variable. The study of [27] determined the problem that the performance level of employees at PT. Mopoly Raya is not ideal, the existence of problems in the work environment that affect the achievement of the optimal performance of the workers, and the inability of individuals to divide their time at work and get enough time after work, and a feeling of job dissatisfaction and this is due to the work environment of the organization. The study aimed to determine and analyze the impact of the quality of work life and work participation on the performance of workers in the presence of job satisfaction as a mediating variable, for a sample of (70) permanent workers at the center for operational activities in PT. Mopoly Raya In Indonesia, and the most prominent results, the (QWL) has a positive and significant effect on job satisfaction a value of (0.702), and (QWL) has a positive and significant impact on the performance of workers with a value of (0.286), there is also an impact relationship for QWL on the performance of Worker through job satisfaction with a value of $(0.222)$. 
A review of the dependent variable in entrepreneurial thinking

From the standpoint of intellectual and technological progress and the instability of the external environment, organizations need to impress mentally the mind of individuals to deal with the rapidly changing business environment. As the pioneering thinking broadens the horizon and the ability to face the challenges faced by profitable organizations, especially non-profit organizations, which are urgently needed, in order to sustain and improve their position in the business world, the study of [25] came with the problem of the monopoly of old or new businessmen in projects, their technologies, ideas and ability that distinguish them and their work in any industry. It is difficult to know ways to maintain their place at the top in the sense that the greater the importance of the creativity presented by the entrepreneur the more difficult it is for the Others to imitate it, and as the bakery industry is considered one of the important amounting to (75\%) in the state of Delta, and therefore it requires research into the way of thinking of entrepreneurs and skills that managers or project owners will need to make, superior strategies for customer value. The study aimed to clarify the relationship between Entrepreneurial thinking \& competitiveness of entrepreneurs in the countryside and the ban in the bakery industry in the Delta, with a sample size of (20) entrepreneurs, and the most important results are the presence of distinction between creativity and a competitive advantage for businessmen by (3.39), and there is no significant difference between the average classification of entrepreneurs, as urban areas came with a size of (12) participants, and an arithmetic average was (20.25) with a standard deviation (7.09). The size of (8) participants and an arithmetic average of (16.02) with a standard deviation (3.40), and a study [4] with a problem, banks suffer a lack of interest in the quality of banking service, neglect of the role of leadership and pioneering thinking in enhancing it, and the need to clarify this role in activating the field of entrepreneurial thinking to activate the state of competition for the individual and the organization. The aim of the study is the existence of a significant and moral correlation between both leadership and entrepreneurial thinking and its dimensions and service quality Banking, with a sample of (14) from the assistant general manager, and the directors of the banking departments of Babil, Sumer, the Arabian Gulf, the Islamic, and Warka in Najaf province in Iraq. The most important results emerged, dimensions of entrepreneurial thinking occupied both creativity, anticipation and exclusivity of equal good relative importance. The dimension of adopting the highest risk was the most important, and the dimensions of the quality of banking service for both reliability, responsiveness and dealing mechanisms occupied good importance, while the dimension of the tangible aspects was of the highest importance and the dimension of safety was the least important.

Accordingly, our study was characterized with a good sample size included department directors and their assistants and people in the middle management, and application in a government service sector by adopting the (QWL) as an independent variable and entrepreneurial thinking as a dependent variable. The aim of the research is to measure the level of availability of the dimensions of the QWL and Degree of awareness importance of entrepreneurial thinking among the responsible individuals, the study sample, and to diagnose the nature of the relationship and influence between the two variables, and the research community is represented in the Iraqi Ministry of Labor and Social Affairs in which a sample of (214) people was selected.

\section{THE THEORETICAL FRAMEWORK}

Concept and dimensions of work life quality

In [22] indicated that the concept of (QWL) is " reaction of individuals working their jobs, especially the conditions to satisfy professional requirements and their intellectual health in accordance with personal growth, scientific experience and methods of improving work" [12], as indicated by the American Association (T \& D) the concept of the (QWL) is " a process of organizations that enables its employees at all levels to participate and busily in shaping Work environment, Means \& outputs" [19], and [21] explained the concept of quality of life as " individual's perception of well-being, conditions, situation, or the general atmosphere and the experience of individuals working in the organization, which indicates the effectiveness of the organization's environment in meeting their personal needs." Accordingly, in light of the above, the two researchers provide a definition that the (QWL) is a decent work environment individual starting from the axis of his standing in his work land, which covers the needs of individuals, ensures their satisfaction and meets the requirements of the organization, thus contributing to raising the level of productivity and excellence in the world of business.

\section{The current study relied on the highest important dimensions of the (QWL) is}

- Wages and rewards: [23] indicated that wage is an important part of working life, because the most important tools for To attract working individuals, it is a major component to assess (QWL), as many studies discovered that the level of income It has a great impact on job satisfaction, and that individuals with higher income are more comfortable in the essence of their profession, which encourages more assumption of tasks and responsibilities.

- Organizational climate: [28] indicated that the organizational climate is the pattern of social interaction that characterizes any organization that relies on justice and fairness and is considered a necessity in the (QWL) and achieving beneficial results for working individuals. 
- Staff training and development: It refers to developing human capabilities, and focuses on raising the level of their behavior by conducting training according to the needs of the organization, to improve their ability to investment resources such as capacity, time ,etc. for the contribute to increasing quality, and the (QWL) is achieved if working individuals have obtained training opportunities, and the maintenance of high-quality human resources leads to improvement and sustainability of operations [29].

- Opportunities for promotion and career advancement: It refers to personal growth and creating fields for career advancement and is linked to several aspects, including developing the capabilities of working individuals, knowledge and the possibility of using those acquired skills in future work tasks [22].

- The material and moral work environment: In order to build a material and moral work environment [24], the management of organizations must provide the necessary resources to accomplish good work and moral appreciation, such as providing work supplies such as tools, equipment, time, information and support that they receive Individuals working on their job duties by the higher management, whatever results achieved, and ensuring that there are sufficient human resources to cover the workload and professional effort provided and that is appreciated.

- Health conditions and occupational safety: The main focus in the workplace lies in the workforce, so safe and healthy working conditions should be provided [2].

The concept and dimensions of entrepreneurial thinking

The concept of entrepreneurial thinking is the ability to think what the future can carry, and to share the basic activities in order to arrange a fruitful work through a mentality specialized in the initiative of the individual, it points [20]. The concept of entrepreneurial thinking is the organization's thinking about how to innovate in a constrained environment with limited resources and a labor market approach, while [25] explained that he dealt with a new idea as an empowerment of a businessman to do something ever in a different way from people. Accordingly, in light of the above, the two researchers clarify that the concept of entrepreneurial thinking is the ability to see a new and valuable vision, whether the creation of ideas or development, and requires the initiative to achieve them, which contributes to creating a sustainable competitive advantage for organizations. The pioneering thinking is not an innate or hereditary matter, but rather it is acquired and occurs by learning and experience, and by looking at some relevant studies, it was found that the dimensions of entrepreneurial thinking are not classified within the multiple dimensions, and it was noticed that their dimensions overlap with the field of entrepreneurship, strategic leadership and entrepreneurial orientation, and among the most important dimensions entrepreneurial thinking adopted by the study is:

- Invention: And [4] showed that creativity is the main element in entrepreneurial thinking because it supports the entity of the organization, brings everything new and narrows its value, and thus the organization achieves a pioneering and distinguished position in providing its products, whether in goods or services.

- Proactive: [17] indicated that maintaining proactivity is essential in the culture of the organization, and that the first initiative for organizations is through the transfer of competitive advantages to their advantage.

- Embrace risk: Drucker has shown that an entrepreneur does not make rash decisions, but is reasonably aware of the risks and has the ability to calculate and manage these risks [26].

- Uniqueness or distinction: It is considered "a group of distinguished activities and actions that enhance the organization's ability to reach entrepreneurship, through its superior awareness of strategic success factors, including resources, organizational structure, organizational culture and quality" [10].

\section{RESEARCH METHODOLOGY}

This research reviews presentation of the study problem, its importance, objectives and hypotheses, methods of data collection and statistical measures, the study community and sample, the study methodology and tool as follows:

\section{The problem of the study}

Through the initial survey of the Iraqi Ministry of Labor and Social Affairs and its affiliated bodies and departments, the two researchers noticed the existence of a traditional response in achieving the ministry's objectives and the services provided. This affects the level of progress in the ministry, and the reason is due to the weak working environment conditions for working individuals, So affects in efficiency of their performance and the failure to show their abilities and creative ideas while performing their work in a routine manner, the extent of suffering is clear for some individuals working during field interviews and listening to them, the presence of weak requirements and needs in the work environment and the lack of financial allocations as a result of economic and the current health conditions, in light of the foregoing, the idea of the study problem was generated in the following question:

What is the effect of the quality of work life in the entrepreneurial thinking for surveyed ministry?

Through main problem, a series of questions were raised to solve them as follows: 1) What is the degree of availability of the (QWL) dimensions as perceived by the working individuals, the study sample in the surveyed ministry ?,2) What is the level of awareness of the importance of entrepreneurial thinking among the working 
individuals, the study sample in the studied ministry ?, 3) What is the relationship between the QWL dimensions and level of entrepreneurial thinking ?, 4) What is a degree of influence of QWL and dimensions on the entrepreneurial thinking of the studied ministry?

\section{Significance of The Study}

From the scientific point view, concerned with the vital aspect of organizations and seeks to provide theoretical knowledge and to enrich information in the areas of management and to understand the role played by individuals with entrepreneurial thinking in light of rapid changes, which confirms the need for quality in the work environment and attention to it. Reflected on the organization's progress, as well as the existence of a knowledge gap through a review of previous studies and research. The study contributes to the formation of an integrated model linking the dimensions of the QWL (wages \& rewards, organizational climate, training \& development of workers, opportunities for Upgrading \& career advancement, physical and moral work environment, health conditions) and entrepreneurial thinking, to encourage organizations to increase their awareness in adopting these methods in order to raise their performance and position and provide the best outputs, and from the practical point of view their importance is derived from the results study, knowledge of deficiencies and making recommendations. the study contributes to enhancing and improving the quality of work life and entrepreneurial thinking to develop its plans and strategy that help raise the profile of ministry.

Target of the study: In line with the study questions, this study seeks to achieve the following Targets

- Measuring the degree of availability of (QWL) dimensions according to the perception of working individuals, the study sample in the studied ministry.

- Measuring the level of perception of the importance of entrepreneurial thinking among working individuals, the study sample in the studied ministry.

- Examining the relationship between (QWL) dimensions and the level of entrepreneurial thinking in studied ministry.

- statement the degree of influence of the (QWL) with its dimensions on the entrepreneurial thinking of the studied ministry.

Hypotheses of the study: The study hypotheses were represented by

The first main hypothesis: There is a statistically significant correlation between the (QWL) \& entrepreneurial thinking six secondary hypotheses emerge from it:

- There is a statistically significant association between wages \& rewards and entrepreneurial thinking.

- There is a statistically significant correlation between organizational climate and entrepreneurial thinking.

- There is a statistically significant correlation between employee training \& development and entrepreneurial thinking.

- There is a statistically significant correlation between promotion opportunities, career advancement and entrepreneurial thinking.

- There is a significant statistically correlation between the material \& moral work environment and entrepreneurial thinking.

- There is a statistically significant correlation between health conditions, occupational safety and entrepreneurial thinking.

The second main hypothesis: There is a significant, statistically significant effect of the (QWL) in entrepreneurial thinking. Six secondary hypotheses emerge from it, as shown in figure 1:

- There is a significant statistical effect of wages \& rewards in entrepreneurial thinking.

- There is a statistically significant impact of the organizational climate in entrepreneurial thinking.

- There is a statistically significant impact on training \& developing employees in entrepreneurial thinking.

- There is a statistically significant effect of promotion opportunities and career advancement in entrepreneurial thinking.

- There is a statistically significant impact of the material \& moral work environment in entrepreneurial thinking.

- There is a statistically significant impact of health \& occupational safety conditions in entrepreneurial thinking. 


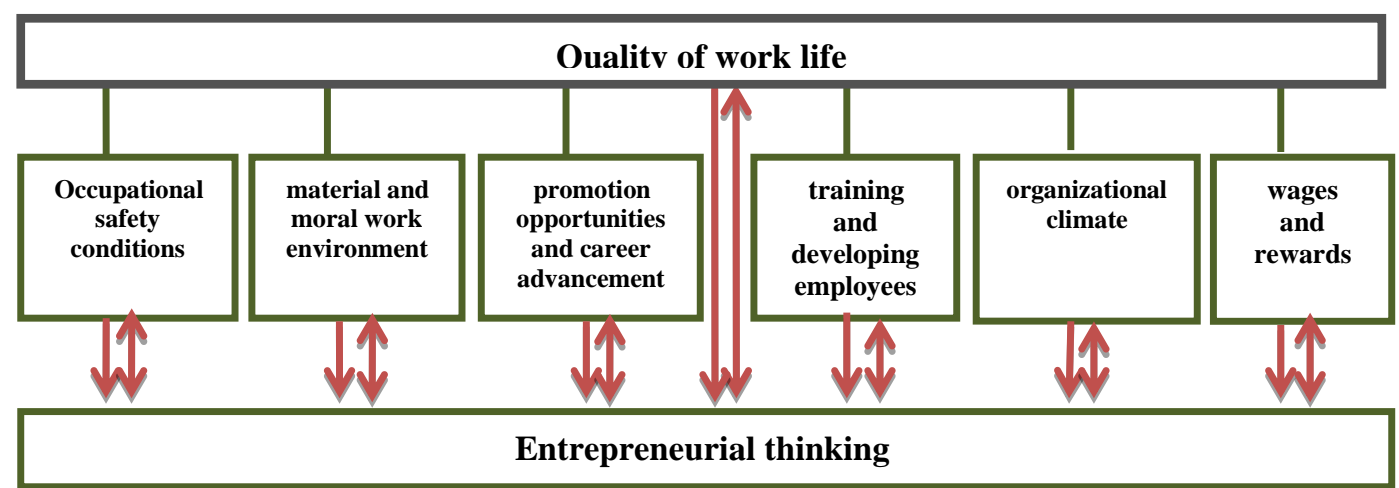

Fig 1: The hypothetical outline of the study

Collecting data, information and statistical measures

With regard to the theoretical side of the study, various sources have been relied upon, including books, theses, dissertations, journals, articles and scientific conferences in the Arabic and foreign languages. The practical side of the study is to use a structured questionnaire to collect data on study variables and interpret them according to the Likert five-point scale with a distance ranging between $\{(1=$ Not completely agree $)-(5=$ completely agree $)\}$ to measure the position of survey, as it is one of the most clear and accurate measures used in administrative and social sciences [12], in addition to field visits and personal interviews. As for the statistical measures, a coefficient was used. Cronbach's Alpha reliability considered of the most accurate measures. and used to indicate the reliability of the data we obtained from the distribution of the questionnaires to the respondents. The higher the value of this indicator is more than (0.700), the higher the reliability (quality, 2009: 298), and the weighted arithmetic mean is defined as the most prominent and accurate measures of central tendency, as it gives a value that indicates an initial meaning of the nature of the data and uses the weighted arithmetic mean to determine the level of responses Individuals of the sample on the paragraphs of the questionnaire [6], and express it by the following formula:

$$
\bar{x}=\frac{\sum x i w i}{\sum w i}
$$

$\mathrm{xi} \mathrm{wi}=\sum=$ Total sum (multiplied by each view $*$ its weight), wi $=\sum=$ size of the sample, and the standard deviation that indicates extent of homogeneity or harmony of the respondents' answers in terms of their proximity to their arithmetic mean [6], and is expressed by the following equation:

$$
\mathrm{S}=\sqrt{\frac{\sum_{i=1}^{n}(x i-\bar{x})^{2}}{n-1}}
$$

$\mathrm{S}=$ sample standard deviation, $\mathrm{x}=$ average, $\mathrm{xi}=$ observed value, $\mathrm{n}=$ number of observed values

and the relative importance is a statistical measure that expresses the relative weight of the weighted arithmetic mean and we get it by dividing the weighted arithmetic mean for each paragraph by the largest score taken by the five-factor Likert scale, which is equal to five multiplied by a hundred, and Spearman's scale correlation coefficient is used to measure the strength and nature of the correlation relationship between two variables [9], and expressed in the following formula:

$$
\mathrm{R}=1-\frac{6 \sum d i^{2}}{n\left(n^{2}-1\right)}
$$

And the statistical laboratory (Z-TEST) documents the significance of the correlation between two variables if the sample size is more than thirty, in other words it is used to test the correlation hypotheses [9].

\section{$\mathrm{Z}=$ simple correlation coefficient multiplied by the root of the sample size minus one}

The statistical test (F-TEST) is used to indicate the significance of the Influence linear between the (X) variables $\&(\mathrm{Y})$ variable. And If the calculated number of $(\mathrm{F})$ greater than its tabular F counterpart, which is likely to have a significant effect for the independent variable in the dependent variable, otherwise the effect hypothesis is rejected [9]. About it by the following equation:

\section{$\mathrm{F}=$ (Moderate sum of squares of the regression) / (Moderate sum of squares of error)}

And determination coefficient (R2) is Apply to find out the ratio effect (X) variable in (Y) variable, and it is sometimes called the interpretation factor [9], and Stepwise, which uses this advanced statistical method to diagnose the dimensions of the independent variable most influencing In the dependent variable [11], the study 
relied in the data analysis process on the ready-made statistical analysis program Amos v.25, Excel v.10 and SPSS v. 25 program.

\section{Study community and sample}

Sugiyono describes the community as the generalization scope consisting of topics and goals that have specific characteristics that the researchers define for the study, and then draw conclusions [27]. Based on the study problem and its objectives, the study community of Ministry of Labor and Social Affairs, whose number is (478) individuals from the middle management level in the bodies and departments of the ministry that are surveyed as for the study sample is a stratified random sample consisting of department directors and their assistants and people officials in the bodies and departments of the ministry, and the sample size was determined to (214) individuals using a law Krejcie \& Morgan in 1970 and the most accurate in determining the sample size [5], as the study community is well represented.

\section{Study methodology and tool}

The study adopted the descriptive approach because studying describing sample and its diagnosis, and to trying to find the relationship between the two variables, and analytically based on analyzing the data collected through the questionnaire. This approach is suitable for studies that seek knowledge and access to the relationship between the variables and the effects of that relationship, questionnaire was used as a main tool for the study according to the five-year Likert scale, and attention was also paid to when drafting the paragraphs of the questionnaire after being judged by a group of expert referees with competence and necessary adjustments were made in light of their valuable suggestions, as the questionnaire consists of three Paragraphs, the first section devoted general data and the amount of (6) paragraphs, and as mentioned by [30] that any studies presented without investigation and analysis in the demographic characteristics of workers, will reveal only half of the legend, and the second section devoted a variable of quality of work life, which amounted to (34) paragraphs, according to the sources of measurement [15], [9], [30], [14], and the third section is the dependent variable of entrepreneurial thinking, which amounts to (23) paragraphs according to According to its measurement sources [7], [8], [3], and [1].

\section{PRACTICAL FRAMEWORK}

Results of reliability test by Cronbach's Alpha for work life quality and entrepreneurial thinking

The value of Cronbach's Alpha coefficient for all paragraphs of the questionnaire Appeared (0.970), it is Greater than (0.700), Means skip fifty-seven paragraphs to successfully Reliability, as indicated by [18] by showing a reliability index higher than (0.70) that is satisfactory internal consistency, table 1 confirms that all six dimensions of the (QWL) have been skipped to successfully test the stability, especially since all the values of Cronbach's Alpha have formed values of more than (0.700), as well as skip all four dimensions of entrepreneurial thinking (creativity, anticipation, risk-taking, uniqueness) to successfully test stability, especially since all Cronbach's Alpha factor values have Its value exceeded (0.700).

Table 1: Results of stability test according to Cronbach's Alpha method

\begin{tabular}{|c|c|c|c|c|}
\hline \multicolumn{2}{|r|}{ Study variables } & Cronbach's & Reliability & Interpretation of results \\
\hline $\mathbf{X 1}$ & Wages and bonuses & 0.808 & High & \multirow{13}{*}{$\begin{array}{l}\text { There is a high stability in } \\
\text { all items of the questionnaire }\end{array}$} \\
\hline $\mathbf{X 2}$ & Organizational climate & 0.834 & High & \\
\hline $\mathbf{X 3}$ & Staff training and development & 0.841 & High & \\
\hline $\mathbf{X} 4$ & $\begin{array}{r}\text { Opportunities for upgrading and career } \\
\text { advancement }\end{array}$ & 0.844 & High & \\
\hline $\mathbf{X 5}$ & physical and moral Job environment & 0.818 & High & \\
\hline X6 & Occupational health and safety & 0.779 & High & \\
\hline $\mathbf{X}$ & Quality of work life & 0.946 & High & \\
\hline Y1 & Invention & 0.817 & High & \\
\hline Y2 & Preemptive & 0.885 & High & \\
\hline Y3 & Embrace risk & 0.851 & High & \\
\hline Y4 & Uniqueness & 0.811 & High & \\
\hline $\mathbf{Y}$ & Entrepreneurial thinking & 0.951 & High & \\
\hline \multicolumn{2}{|c|}{ All paragraphs of the questionnaire form } & 0.970 & High & \\
\hline
\end{tabular}

Source: The results of the electronic calculator according to the data of the SPSS v.25 program.

\section{Results of adjective analysis of general data}

Table 2 results of descriptive analysis of general data indicates that the percentage of males among the respondents was the most at $(55.14 \%)$, but the percentage of females among the total sample members was recorded $(44.86 \%)$. This is due to the fact that the study community is male and that females are less likely than men to assume 
administrative positions in the bodies and departments of the ministry, as well as their personal and social responsibility. So there is still a gap, and that the age group (from 40 years to less than 50 years) constituted the highest percentage among the respondents, reaching (37.38\%), followed by the percentage of those of their ages within the category (from 50 years and over) and by (34.58\%), which confirms that most of the occupants of the middle management in the Ministry of Labor and Social Affairs possess extensive experience in professional life that qualifies them to occupy these positions, while the lowest percentage among the sample members of their ages under thirty years of age, by (4.21\%), and that the percentage of holders of a bachelor's degree from middle management in the surveyed ministry was the most, reaching $(74.30 \%)$, while the percentage of those with a diploma was $(12.15 \%)$ and those with higher degrees were doctorates, masters and higher diplomas, and by ( $0.93 \%+9.35 \%+3.27 \%=13.55 \%$ ), which are few percentages in the ministry. This is attributed to the fact that the individual did not have the desire to complete his education, or vice versa, but was unable to overcome obstacles and stopped half way and was satisfied with a bachelor's degree in positions. Personnel employed who were FT The number of people who have served them from twenty years or more, represented a high percentage among the respondents, as their percentage reached (42.52\%). This is followed by the percentage of employees whose service period ranged from fifteen years to less than 20 years at a rate of $(27.57 \%)$, indicating that the ministry owns a workforce in middle departments with extensive and long job experience, while the percentage of those who have years of service from one year to less than ten years or more, the lowest percentage among respondents is (10.28\%), which confirms the Ministry's accreditation of competencies that have great experience in administrative positions, as well as which increases the accumulation of experiences and gives individuals a clear perception of an answer to the paragraphs of the questionnaire, and that the percentage of people officials in the studied sample reached (47.20). We find that category the largest number, and this corresponds to the career ladder and the organizational structure in the public sector organizations, while the percentage of assistant mangers reached (19.62\%), which is the lowest percentage among the respondents to the questionnaire, which indicates that some departments do not have an assistant manager, because the number of assistants in the departments is not equal to the number of department directors. This may be due to the retirement of old employees and their place became vacant, and that the percentage of those working in the Social Protection Authority in the studied sample was the most as it reached (21.02\%), while the percentage of the respondents' families in the office of the Child Care Authority $(0.47 \%)$, which is the lowest percentage among the sample members, naturally, this is due to the nature of the bodies 'work tasks and the number of workers therein according to the distribution of the organizational structure.

Table 2: Results of descriptive analysis of general data

\begin{tabular}{|c|c|c|c|}
\hline Feature & Category & Number & Percentage $\%$ \\
\hline \multirow{3}{*}{ Social type } & Male & 118 & $55.14 \%$ \\
\hline & Female & 96 & $44.86 \%$ \\
\hline & Total & 214 & $100 \%$ \\
\hline \multirow{4}{*}{ The age } & Less than 30 years & 9 & $4.21 \%$ \\
\hline & From 30 years old to less than 40 years old & 51 & $23.83 \%$ \\
\hline & From 40 years old to less than 50 years old & 80 & $37.38 \%$ \\
\hline & From 50 years and over & 74 & $34.58 \%$ \\
\hline & Total & 214 & $100 \%$ \\
\hline \multirow{6}{*}{$\begin{array}{l}\text { Scientific } \\
\text { qualification }\end{array}$} & $\mathrm{PhD}$ & 2 & $0.93 \%$ \\
\hline & M.A. & 20 & $9.35 \%$ \\
\hline & Higher Diploma & 7 & $3.27 \%$ \\
\hline & Bachelor & 159 & $74.30 \%$ \\
\hline & Diploma & 26 & $12.15 \%$ \\
\hline & Total & 214 & $100 \%$ \\
\hline \multirow{5}{*}{ Service years } & (1 year - lower than 10 years) & 22 & $10.28 \%$ \\
\hline & (10 years - lower than 15 years) & 42 & $19.63 \%$ \\
\hline & ( 15 years - lower than 20 years) & 59 & $27.57 \%$ \\
\hline & From 20 years and over & 91 & $42.52 \%$ \\
\hline & The total & 214 & $100 \%$ \\
\hline \multirow{4}{*}{ Job title } & Director of the Department & 71 & $33.18 \%$ \\
\hline & Associate director of the department / reserve & 42 & $19.62 \%$ \\
\hline & Division Officer & 101 & $47.20 \%$ \\
\hline & The total & 214 & $100 \%$ \\
\hline \multirow{4}{*}{$\begin{array}{l}\text { The office we } \\
\text { work in }\end{array}$} & Social Protection Authority & 45 & $21.02 \%$ \\
\hline & $\begin{array}{l}\text { Authority for the Care of People with Disabilities and } \\
\text { Special Needs }\end{array}$ & 34 & $15.89 \%$ \\
\hline & Retirement and social security for workers & 31 & $14.49 \%$ \\
\hline & National Center for Occupational Health and Safety & 18 & $8.41 \%$ \\
\hline
\end{tabular}




\begin{tabular}{|c|c|c|c|}
\hline \multirow{4}{*}{} & Child Care Authority Office & $\mathbf{1}$ & $\mathbf{0 . 4 7 \%}$ \\
\cline { 2 - 4 } & Work and professional training & $\mathbf{4 0}$ & $\mathbf{1 8 . 6 9 \%}$ \\
\cline { 2 - 4 } & Projects and Reconstructions & $\mathbf{9}$ & $\mathbf{4 . 2 1 \%}$ \\
\cline { 2 - 4 } & Administrative and financial & $\mathbf{2 1}$ & $\mathbf{9 . 8 1 \%}$ \\
\cline { 2 - 4 } & Planning and studies & $\mathbf{9}$ & $\mathbf{4 . 2 1 \%}$ \\
\hline & Legal & $\mathbf{6}$ & $\mathbf{2 . 8 0 \%}$ \\
\hline
\end{tabular}

Source: Excel v.10.

Results of the adjective analysis of the study variables

the study uses the direction of the respondent's response to the items of the questionnaire is determined by the hypothetical mean of (3) it the limit among agreement \& dis-agreement in five-point Likert tally, and study is based on the response strength matrix of the respondent and as indicated in table 3.

Table 3: Matrix the reply strength of the respondents on the paragraphs of the questionnaire

\begin{tabular}{|c|r|r|r|}
\hline Category & $\begin{array}{c}\text { The weighted average number is } \\
\text { limited between }\end{array}$ & $\begin{array}{c}\text { The strength to the reply to the } \\
\text { paragraphs }\end{array}$ & $\begin{array}{c}\text { The response level by } \\
\text { the Sample }\end{array}$ \\
\hline $1^{\text {st }}$ & From 1 to less than 1.8 & I don't completely agree & Too low \\
\hline $2^{\text {nd }}$ & 1.8 to less than 2.6 & I do not agree & Mow low \\
\hline $3^{\text {rd }}$ & 2.6 to less than 3.4 & Agreed & High \\
\hline $4^{\text {th }}$ & From 3.4 to less than 4.2 & Totally agree & very high \\
\hline $5^{\text {th }}$ & 4.2 to 5 &, Publing \\
\hline
\end{tabular}

Source: Karnilev Sergey Sergeyevg [13] Multiple Regression, Publishing House, Statistical Sciences Library, Moscow-Russian Federation: 215.

Outcome of a descriptive analysis of the level of the respondents' answers to the paragraphs of the independent variable $(Q W L)$

Table 4 generally documents the outcome of the statistical analysis of the level of the respondents' responses to the paragraphs and dimensions of the QWL, as the results indicated that value of the weighted arithmetic mean of the quality of work life. As the (X) variable was Appeared (3.898), meaning of is greater than the Number of the hypothetical mean that act the limit between the agreement and dis-agreement amounting to (3), confirming that direction of the answers related the quality of work life tended towards agreement, while the response level of the respondent to most of the paragraphs of the quality of work life was at a high level, especially since number of the weighted arithmetic mean of the (QWL) within the category that ranges from (from 3.4 to less than 4.2) in the responder strength matrix. The value of the standard deviation of the quality of work life was $(0.888)$, which indicates the presence of consistency in the sample responses to the paragraphs of the QWL, while the relative importance of the (QWL) was recorded (77.96\%), which documents the agreement of most of the studied sample members on the paragraphs of the quality of working life. Thus, we conclude that the middle departments in the ministry are significantly concerned with the quality of work life and its six dimensions, but the nature of interest was in varying proportions, and the statistical analysis shows that top reply level by the sample achieved by a Organizational climate dimension among all other dimensions of the quality of working life with a weighted arithmetic average of (4.016), and (sd) of (0.766), a relative magnitude that formed $(80.33 \%)$.

This is what has been observed through field visits, as the institutional values in the Ministry urge to work in the spirit of one team, relying on teamwork and support all work facilities in the bodies and departments of the Ministry of Labor and Social Affairs. While the analysis confirms that wages and bonuses have achieved the down level of reply among the 6 dimensions of work life quality, as the value of the weighted arithmetic average for this dimension was (3.720) with a (sd) recorded (0.928), a relative magnitude of $(74.41 \%)$, confirming this that most of the studied sample agreed that there is less interest on the part of the middle departments in the surveyed ministry over wages and bonuses compared to the rest of the dimensions of the (QWL), which explains the state of economic stagnation and the crisis which lead to insufficient wages and deductions imposed on wages in light of the high cost of living and requirements of life, which contributed to the decline of the desired image of the dimension of wages and rewards, as has been observed in most Arab and foreign studies weakness of this dimension still constitutes the least concern of the organizations, and this is confirmed by [12]. The dimension of fairness of wages and rewards is the most controversial dimension among workers. 
Table 4: The grade of the importance of QWL

\begin{tabular}{|c|c|c|c|c|c|c|c|}
\hline CODE & & Variables & $\begin{array}{l}\text { Weighte } \\
\mathrm{d}\end{array}$ & $\begin{array}{c}\text { (SD) } \\
\text { Standard }\end{array}$ & $\begin{array}{l}\text { relative } \\
\text { importan }\end{array}$ & $\begin{array}{l}\text { Respond } \\
\text { ent's } \\
\text { answer }\end{array}$ & Arrangement \\
\hline $\mathrm{X1}$ & \multirow{5}{*}{ 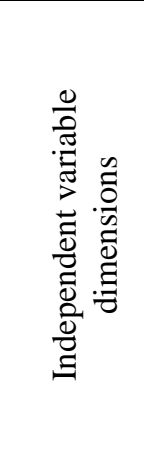 } & Wages and bonuses & 3.720 & 0.928 & $74.41 \%$ & High & $6^{\text {th }}$ \\
\hline $\mathrm{X} 2$ & & $\begin{array}{r}\text { Organizational } \\
\text { climate }\end{array}$ & 4.016 & 0.766 & $80.33 \%$ & High & $1^{\mathrm{st}}$ \\
\hline $\mathbf{X 3}$ & & $\begin{array}{l}\text { Staff training and } \\
\text { development }\end{array}$ & 3.987 & 0.79 & $79.74 \%$ & High & $2^{\text {nd }}$ \\
\hline X4 & & $\begin{array}{r}\text { Opportunities for } \\
\text { promotion and career } \\
\text { advancement }\end{array}$ & 3.875 & 0.998 & $77.51 \%$ & High & $4^{\text {th }}$ \\
\hline X5 & & $\begin{array}{r}\text { The physical and } \\
\text { moral work } \\
\text { environment }\end{array}$ & 3.838 & 0.932 & $76.77 \%$ & High & $5^{\text {th }}$ \\
\hline X6 & & $\begin{array}{l}\text { Occupational health } \\
\text { and safety conditions }\end{array}$ & 3.949 & 0.918 & $\mathbf{7 8 . 9 7 \%}$ & High & $3^{\text {rd }}$ \\
\hline $\mathbf{X}$ & $\begin{array}{l}\text { Independ } \\
\text { ent } \\
\text { variable }\end{array}$ & Quality of work life & 3.898 & 0.888 & $77.96 \%$ & High & \\
\hline
\end{tabular}

Source: The results of the electronic calculator according to the statistical program data SPSS v.25.

Results of a descriptive analysis of the level of the respondents' answers to the item of variable (entrepreneurial thinking)

schedule (5) documents the score for statistical analysis of the level of the respondents 'responses to the paragraphs and dimensions of entrepreneurial thinking, as the results indicated that number of the weighted arithmetic average for entrepreneurial thinking show (3.920), which is greater than number of the hypothetical average that act the boundary between agreement $\&$ dis-agreement, it is three, which confirms that direction of the responses related entrepreneurial thinking tended towards agreement, while the level of the respondent's response to most of the entrepreneurial thinking paragraphs was at a high, especially since of the weighted average of entrepreneurial thinking lies within (3.4 - less than 4.2). The value standard deviation of entrepreneurial thinking was (0.902), which indicates the presence of harmony in the sample responses to the paragraphs of entrepreneurial thinking. As for the relative importance of entrepreneurial thinking, it was recorded (78.39\%), which documents the agreement of most of the studied sample members on the paragraphs of entrepreneurial thinking.

Hence, we conclude that middle administrations in the Ministry of Labor and Social Affairs is significantly interested in entrepreneurial thinking and its dimensions (creativity, Proactive, risk-taking, and Uniqueness), but the nature of the interest was in varying proportions, and the statistical analysis shows that the levels of the studied sample responses on the four dimensions of entrepreneurial thinking, indicate highest answer was proactive dimension amongst the dimensions for entrepreneurial thinking, with a weighted average (3.973) and a (SD) of (0.842), And relativity (79.47\%), which is likely to agree most of the studied sample members on the necessity of being proactive in entrepreneurial thinking, while the uniqueness dimension has achieved the minimum level of reply between the dimensions of entrepreneurial thinking, as the weighted mean value for this dimension reached (3.875) and (SD) reach (0.943), and degree of (77.51\%). This confirms that most members of the studied sample agree that there is less interest on the part of the middle departments in the Ministry of Labor and Social Affairs for individuality compared to the rest of the dimensions of entrepreneurial thinking, as shown in table 5.

Table 5: The level of importance of the dependent variable in entrepreneurial thinking

\begin{tabular}{|c|c|c|c|c|c|c|c|}
\hline Code & & Variables & $\begin{array}{l}\text { Weighted } \\
\text { mean }\end{array}$ & $\begin{array}{l}\text { Standard } \\
\text { deviation }\end{array}$ & $\begin{array}{c}\text { Relative } \\
\text { importance }\end{array}$ & $\begin{array}{l}\text { Respondent's } \\
\text { response level }\end{array}$ & Arrangement \\
\hline Y1 & \multirow{4}{*}{$\begin{array}{l}\text { Independent } \\
\text { variable } \\
\text { dimensions }\end{array}$} & Invention & 3.905 & 0.904 & $78.09 \%$ & Higher & $3^{\text {rd }}$ \\
\hline Y2 & & Proactive & 3.973 & 0.842 & $79.47 \%$ & Higher & $1^{\text {st }}$ \\
\hline Y3 & & Adoption risks & 3.925 & 0.917 & $78.49 \%$ & Higher & $2^{\text {nd }}$ \\
\hline Y4 & & Uniqueness & 3.875 & 0.943 & $77.51 \%$ & Higher & $4^{\text {th }}$ \\
\hline $\mathbf{Y}$ & & $\begin{array}{l}\text { Entrepreneurial } \\
\text { Thinking }\end{array}$ & 3.920 & 0.902 & $78.39 \%$ & Higher & \\
\hline
\end{tabular}


Source: The results of the electronic calculator according to the data of the statistical program SPSS v.25.

\section{STATISTICAL TEST RESULTS FOR THE STUDY HYPOTHESES}

The correlation between the quality of work life in its six dimensions and the entrepreneurial thinking

- The research relies on using the statistical laboratory (Z-TEST) to test the hypotheses of correlation between the quality of work life in its six dimensions (wages and rewards, organizational climate, employee training and development, Job promotion opportunities, physical \& moral work environment, health conditions and occupational safety) and between the dependent variable represented in entrepreneurial thinking, as the correlation hypothesis will be accepted when it is number (Z) is greater than tabular number of (1.96) at a significant level (5\%), therefore accepting the hypothesis with a confidence rate (95\%), at the same time the value of the correlation coefficient between the variables is accompanied in the results of the statistical analysis of the SPSS program a. sign (** or *), especially since $(* *)$ means acceptance of the hypothesis at a significant level. (0.01) As for the sign (*), it means acceptance of the hypothesis at a level of significance equal to (0.05). The characteristics of Spearman's correlation coefficient, and the test results were according to Table (6) as follows:

- The correlation between wages \& rewards and entrepreneurial thinking: as the results of the statistical laboratory (Z-TEST) documented the acceptance of the first secondary hypothesis and a trust rate of $(0.95)$, (Z) value of (9.559), it is more than of tabular (Z), at a significant level (5\%), the correlation coefficient among wages \& rewards and entrepreneurial thinking was recorded $\left(0.655^{* *}\right)$ to indicate that there is a strong correlation between wages and bonuses as one of the dimensions of the quality of work life and the entrepreneurial thinking according to the opinions of the sample.

- The correlation among organizational climate and entrepreneurial thinking: as the results of the statistical laboratory (Z-TEST) documented the acceptance second secondary hypothesis, with a trust rate (95\%). As the (Z) value of (10.917), it is senior than the value of the tabular (Z) at a significant level (5\%), and the value of simple correlation coefficient among organizational climate and entrepreneurial thinking was $(0.748 * *)$ to indicate that a strong correlation among the organizational atmosphere as one of the dimensions of the quality of work life and the entrepreneurial thinking according to the opinions of the members of the studied sample.

- The correlation between employee training \& development and entrepreneurial thinking: as the results of the statistical laboratory (Z-TEST) documented acceptance of the third secondary hypothesis, a percentage of a trust ( $95 \%)$, as the value of $(\mathrm{Z})$ was $(10.844)$, it is more than $(\mathrm{Z})$ tabular at a significant level (5\%), and the value of the simple correlation coefficient among employee training and entrepreneurial thinking was $(0.743$ **). To document this, there is a strong correlation between employee training and development as one of the dimensions of work life quality and entrepreneurial thinking according to the opinions of the studied sample.

- The correlation between promotion opportunities and career advancement and entrepreneurial thinking: as the results of the statistical laboratory (Z-Test) documented the acceptance of the fourth secondary hypothesis, with a percentage a trust (95\%), the value of $(\mathrm{Z})$ was (10.391), it is more than the value of tabular $(\mathrm{Z})$, at significant level (5\%), the value of a simple correlation coefficient among promotion opportunities and career advancement and entrepreneurial thinking was $(0.712 * *)$. This confirms that there is a strong correlation between promotion opportunities and career advancement as one of the dimensions of work life quality and entrepreneurial thinking according to the opinions of the studied sample members.

- The correlation between the material \& moral work environment and the entrepreneurial thinking: as the results of the statistical laboratory (Z-Test) documented the acceptance of the Fifth secondary hypothesis, trust percentage was (95\%), as the value of $(\mathrm{Z})$ was (10.056), it is more than the value of the tabular $(\mathrm{Z})$, at a significant level (5\%), and the value of the simple correlation coefficient among the material \& moral work environment and the entrepreneurial thinking was $(0.689 * *)$ This indicates the existence of a strong correlation among the material and moral work environment as one of the dimensions of the (QWL) and the entrepreneurial thinking according to the opinions of the studied sample.

- The correlation between occupational health and safety conditions and entrepreneurial thinking: as the results of the statistical laboratory (Z-TEST) documented the acceptance of the sixth secondary hypothesis with a percentage trust $(95 \%)$. The calculated $\mathrm{Z}$ value was (10.625), it is more than the tabular value of $(\mathrm{Z})$, at a significant level (5\%), the value of the simple correlation coefficient among health conditions \& occupational safety and entrepreneurial thinking was $(0.728 * *)$. a strong correlation between health conditions and occupational safety as one of the dimensions of the quality of work life and entrepreneurial thinking according to the opinions of the studied sample.

- The correlation between the QWL and entrepreneurial thinking: as the results of the statistical laboratory (ZTEST) documented the acceptance of the first main hypothesis with a confidence ratio of $(95 \%)$. The calculated $\mathrm{Z}$ value was (12.478), it is greater than the tabular $\mathrm{Z}$ value of at a significant level (5\%), and the value of the correlation coefficient among the quality of work life and entrepreneurial thinking was $(0.855$ **), which documents a strong relationship between the QWL and the entrepreneurial thinking, as table 6 confirmed the acceptance of six secondary hypotheses stemming from the first main hypothesis, bringing the number of acceptable correlation hypotheses to seven out of seven hypotheses (one main and six secondary 
hypotheses stemming from it) to reach the percentage of the number of the accepted correlation hypotheses between the (QWL) in its six dimensions and the dependent variable in entrepreneurial thinking reach (100\%), and the organizational climate emerged with the highest correlation with entrepreneurial thinking, documenting the importance of the organizational climate in achieving entrepreneurial thinking, followed by (training and development, health conditions \& occupational safety, opportunities for promotion \& career advancement, the material \& moral work environment) in order of strength of relationship with entrepreneurial thinking, while wages and bonuses recorded the lowest correlation coefficient with entrepreneurial thinking, which confirms that there is little interest on the part of the departments in the Ministry of Labor Social Affairs role Wages and rewards in achieving entrepreneurial thinking.

Table 6: The results of the statistical laboratory for the hypotheses related to the (QWL) in its six dimensions and between the entrepreneurial thinking

\begin{tabular}{|c|c|c|c|c|c|c|}
\hline \multirow{2}{*}{$\begin{array}{l}\text { Hypoth } \\
\text { esis }\end{array}$} & \multicolumn{2}{|c|}{ Variables } & \multirow{2}{*}{$\begin{array}{c}\text { Correlatio } \\
\mathrm{n} \\
\text { coefficient } \\
\text { among } \\
\text { each } \\
\text { variable }\end{array}$} & \multicolumn{2}{|c|}{ Z-test / statistic lab } & \multirow[b]{2}{*}{ Results interpretation } \\
\hline & Independent & dependent & & $\begin{array}{c}\text { Calculate } \\
\mathrm{d} \text { value } \\
\text { of } \mathrm{Z}\end{array}$ & $\begin{array}{l}\text { Possible } \\
\text { value }\end{array}$ & \\
\hline $1-1$ & $\begin{array}{l}\text { Wages and } \\
\text { bonuses }\end{array}$ & $\begin{array}{l}\text { entrepreneurial } \\
\text { thinking }\end{array}$ & $0.655 * *$ & 9.559 & 0.000 & $\begin{array}{l}\text { Acceptance of the first } \\
\text { secondary hypothesis }\end{array}$ \\
\hline $1-2$ & $\begin{array}{l}\text { Organizational } \\
\text { climate }\end{array}$ & $\begin{array}{l}\text { entrepreneurial } \\
\text { thinking }\end{array}$ & $0.748 * *$ & 10.917 & 0.000 & $\begin{array}{l}\text { Acceptance of the second } \\
\text { secondary hypothesis }\end{array}$ \\
\hline $1-3$ & $\begin{array}{c}\text { Staff training and } \\
\text { development }\end{array}$ & $\begin{array}{l}\text { entrepreneurial } \\
\text { thinking }\end{array}$ & $0.743 * *$ & 10.844 & 0.000 & $\begin{array}{l}\text { Acceptance of the third } \\
\text { secondary hypothesis }\end{array}$ \\
\hline $1-4$ & $\begin{array}{l}\text { Opportunities for } \\
\text { promotion and } \\
\text { career } \\
\text { advancement }\end{array}$ & $\begin{array}{l}\text { entrepreneurial } \\
\text { thinking }\end{array}$ & $0.712 * *$ & 10.391 & 0.000 & $\begin{array}{l}\text { Acceptance of the fourth } \\
\text { secondary hypothesis }\end{array}$ \\
\hline $1-5$ & $\begin{array}{c}\text { The physical and } \\
\text { moral work } \\
\text { environment }\end{array}$ & $\begin{array}{l}\text { entrepreneurial } \\
\text { thinking }\end{array}$ & $0.689 * *$ & 10.056 & 0.000 & $\begin{array}{l}\text { Acceptance of the fifth } \\
\text { secondary hypothesis }\end{array}$ \\
\hline $1-6$ & $\begin{array}{l}\text { Occupational } \\
\text { health and safety } \\
\text { conditions }\end{array}$ & $\begin{array}{l}\text { entrepreneurial } \\
\text { thinking }\end{array}$ & $0.728 * *$ & 10.625 & 0.000 & $\begin{array}{l}\text { Acceptance of the sixth } \\
\text { secondary hypothesis }\end{array}$ \\
\hline $\begin{array}{l}\text { The } \\
\text { first } \\
\text { Main }\end{array}$ & Work life quality & $\begin{array}{l}\text { entrepreneurial } \\
\text { thinking }\end{array}$ & $0.855 * *$ & 12.478 & 0.000 & $\begin{array}{l}\text { Accepting the first main } \\
\text { hypothesis that documents } \\
\text { a strong moral link among } \\
\text { the (QWL) and } \\
\text { entrepreneurial thinking }\end{array}$ \\
\hline \multirow{2}{*}{$\begin{array}{l}\text { The } \\
\text { accepte } \\
\mathrm{d} \\
\text { hypoth } \\
\text { eses }\end{array}$} & \multicolumn{3}{|c|}{ Number } & \multicolumn{3}{|c|}{ Seven significant hypotheses out of seven } \\
\hline & \multicolumn{3}{|c|}{$\begin{array}{l}\text { The percentage of the number of hypotheses } \\
\text { accepted }\end{array}$} & \multicolumn{3}{|c|}{$\% 100$} \\
\hline
\end{tabular}

Source: The results of the electronic calculator according to the data of the SPSS v.25 program.

The Impact of work Life Quality in Entrepreneurial Thinking

The research deals with the use of simple linear regression analysis by AMOS v.25 statistical analysis program to demonstrate the nature of the influential relationship among the quality of work life in entrepreneurial thinking and the application of the statistical laboratory (F-TEST) to test the hypotheses of the (QWL) effect in its six dimensions as independent in entrepreneurial thinking as a dependent variable, as the effect hypothesis will be accepted when calculated value (F) higher than its tabular counterpart of (3.9201) at a significant level (5\%), to document acceptance of the hypothesis by $(95 \%)$. The probability value (significance level) corresponding to the calculated $\mathrm{F}$ value is less than the level of significance (0.05). The study used the Coefficient of Determination (\% R2) scale to show the percentage of influence of each dimension of work life quality in entrepreneurial thinking, while to diagnose the impact of each of (wages and rewards, organizational climate, employee training and development, career advancement and promotion opportunities, material and moral work environment. Health conditions and occupational safety (combined in entrepreneurial thinking. The study benefited from the results of 
the AMOS statistical program and multiple linear regression analysis [16], and the results of testing hypotheses for the impact of the (QWL) in its six dimensions in the entrepreneurial thinking according to a table 7 As follows:

- The effect of wages and rewards in entrepreneurial thinking: as the results of the analysis documented the acceptance of the first secondary hypothesis a trust ratio (95\%), as the number (F) reached (151.358), It is more than the tabular $(\mathrm{F})$, at level of significance $(0.05)$, while the value of the coefficient of determination that indicates the percentage the impact of wages and rewards in entrepreneurial thinking was $(41.7 \%)$ according to the opinions of the studied sample.

- The influence of the organizational climate in entrepreneurial thinking: as the results of the analysis documented the acceptance of the second secondary hypothesis a trust ratio $(95 \%)$, as the calculated $(\mathrm{F})$ reached $(259,664)$. especially since it is more than the tabular value $(\mathrm{F})$ at a significant level $(0.05)$, while the value of the determination factor that depicts the percentage of the influence of the organizational climate in entrepreneurial thinking was (55.1\%) according to the opinions of the studied sample.

- The effect of employee training and development in entrepreneurial thinking: as the results of the analysis documented the acceptance of the third secondary hypothesis a trust rate $(95 \%)$, as the (F) value reached (258.426), it is more than the tabular value of $(\mathrm{F})$ at a significant level $(0.05)$, while the value of the parameter of determination, which indicates the percentage of the impact of training and development of workers in entrepreneurial thinking (54.9\%), according to the opinions of the studied sample.

- The effect of promotion opportunities and career advancement in entrepreneurial thinking: The results of the analysis documented the acceptance of the fourth secondary hypothesis a trust rate of $(95 \%)$. The calculated (F) reached (220.659), it is more than the tabular value (F) at a significant level (0.05), while the determination factor related to displaying the percentage of the effect of promotion opportunities and career advancement in entrepreneurial thinking was (51\%) according to the opinions of the studied sample.

- The effect of the material and moral work environment in entrepreneurial thinking: The results of the analysis documented the acceptance of the Fifth secondary hypothesis a trust rate of $(95 \%)$. reached (F) calculated (197.742), is a more than the tabular value $(\mathrm{F})$ at a significant level (0.05), while the value of the determination factor specialized for showing the percentage of the impact of the physical \& moral work environment in entrepreneurial thinking was (48.3\%) according to the opinions of the studied sample.

- The impact of health conditions and occupational safety in entrepreneurial thinking: as the results of the analysis documented the acceptance of the sixth secondary hypothesis a trust rate of $(95 \%)$. The calculated (F) reached (236.643), it is more than the tabular value (F) at a significant level (0.05), while the value of the determination factor specialized in showing the percentage of the impact of health conditions and occupational safety in entrepreneurial thinking (52.7\%) according to the opinions of the studied sample.

- The effect of the quality of work life in entrepreneurial thinking: as the results of multiple linear regression analysis and the AMOS statistical analysis program were documented and that clarified the impact of the Six dimensions of quality of work life combined in entrepreneurial thinking, the value of (F) appeared (100.461), it is more than value $(\mathrm{F})$ tabular, and significant level (0.05). This confirms the acceptance of the second main hypothesis with a trust rate of (95\%), and the coefficient of determination R2\% (74.4\%), thus indicating the percentage of the impact of the six dimensions of the (QWL) combined in entrepreneurial thinking, to become the multiple linear regression equation that expresses the effect linear relationship between (Wages and remuneration, organizational climate, employee training and development, career advancement and promotion opportunities, physical and moral work environment, health and occupational safety conditions) together which symbolizes each of them (X1, X2, X3, X4, X5, X6) on the For successive entrepreneurial thinking, which is symbolized by $(\mathrm{Y})$ as follows, according to table 8 and figure 2

\section{$\mathrm{Y}=0.094+0.13 \mathrm{X1}+0.25 \mathrm{X} 2+0.21 \mathrm{X3}+0.15 \mathrm{X} 4+0.15 \mathrm{X5}+0.16 \mathrm{X6}$}

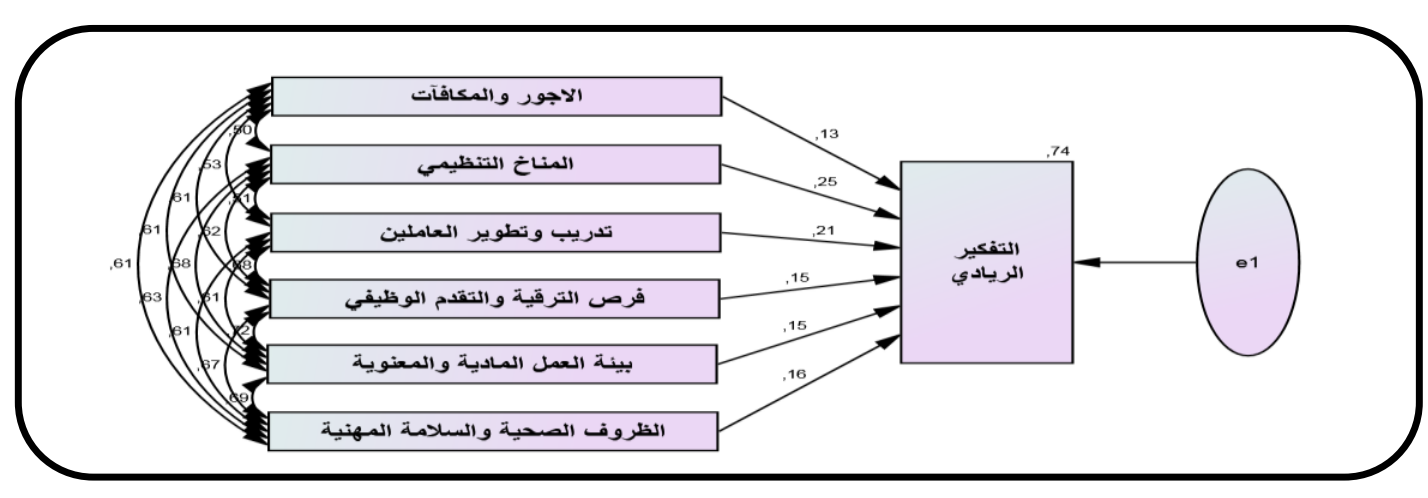

Fig 2: The nature of the influential relationship to the (QWL) in its six dimensions combined in entrepreneurial thinking according to the data of the AMOS program 
Table 7: Results of testing the impact of QWL dimensions in entrepreneurial thinking

\begin{tabular}{|c|c|c|c|c|c|c|c|c|c|}
\hline \multirow[b]{2}{*}{ 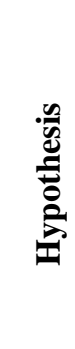 } & \multicolumn{2}{|c|}{ Variables } & \multirow{2}{*}{ 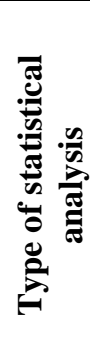 } & \multirow{2}{*}{ 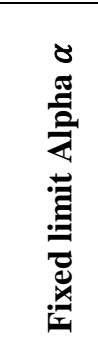 } & \multirow{2}{*}{ 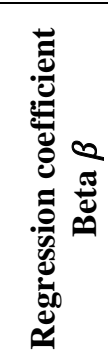 } & \multirow{2}{*}{ 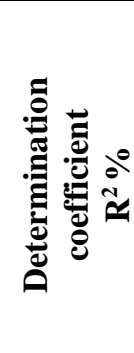 } & \multicolumn{2}{|c|}{$\begin{array}{c}\text { Statistical Lab } \\
\text { F- test }\end{array}$} & \multirow[b]{2}{*}{ Results interpretation } \\
\hline & 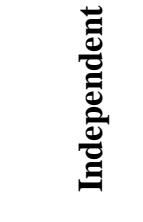 & $\begin{array}{l}\overrightarrow{\overrightarrow{0}} \\
\overrightarrow{0} \\
\overrightarrow{0} \\
\overline{0}\end{array}$ & & & & & 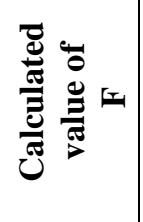 & 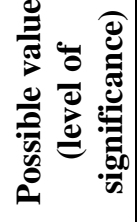 & \\
\hline 2-1 & 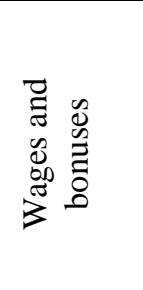 & 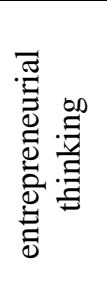 & \multirow{6}{*}{ 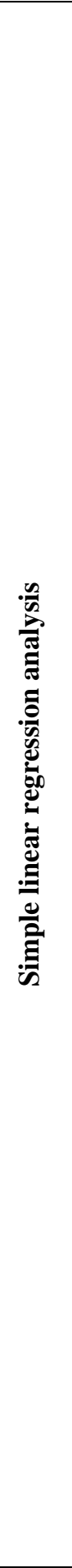 } & 2.190 & 0.465 & $\% 41.7$ & $\begin{array}{c}151.35 \\
8\end{array}$ & 0.000 & $\begin{array}{l}\text { Acceptance of the first } \\
\text { secondary hypothesis, } \\
\text { which documents the } \\
\text { existence of a strong moral } \\
\text { correlation between wages } \\
\text { and rewards and } \\
\text { entrepreneurial thinking }\end{array}$ \\
\hline $2-2$ & 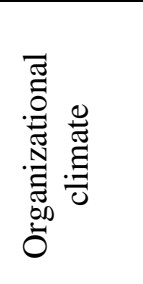 & 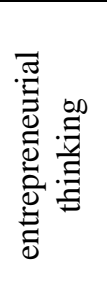 & & $\mathbf{1 . 5 8 7}$ & 0.608 & $\% 55.1$ & $\begin{array}{c}259.66 \\
4\end{array}$ & $\mathbf{0 . 0 0 0}$ & $\begin{array}{l}\text { Acceptance of the second } \\
\text { secondary hypothesis, } \\
\text { which documents the } \\
\text { existence of a strong moral } \\
\text { link between } \\
\text { organizational climate and } \\
\text { entrepreneurial thinking }\end{array}$ \\
\hline $2-3$ & 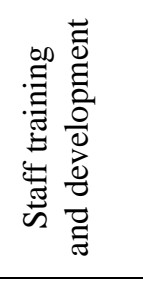 & 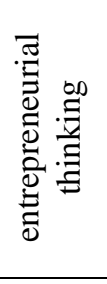 & & 1.493 & 0.626 & $\% 54.9$ & $\begin{array}{c}258.42 \\
6\end{array}$ & 0.000 & $\begin{array}{l}\text { Acceptance of the third } \\
\text { secondary hypothesis, } \\
\text { which documents a strong } \\
\text { moral link between } \\
\text { employee training and } \\
\text { development and } \\
\text { entrepreneurial thinking }\end{array}$ \\
\hline $2-4$ & 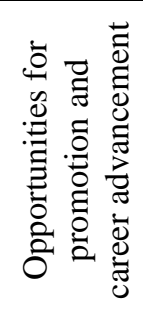 & 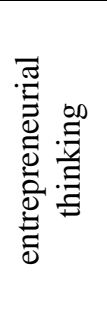 & & 1.347 & 0.652 & $\% 51$ & $\begin{array}{c}220.65 \\
9\end{array}$ & 0.000 & $\begin{array}{l}\text { Acceptance of the fourth } \\
\text { secondary hypothesis, } \\
\text { which documents a strong } \\
\text { moral link between } \\
\text { promotion opportunities } \\
\text { and career advancement } \\
\text { and entrepreneurial } \\
\text { thinking }\end{array}$ \\
\hline $2-5$ & 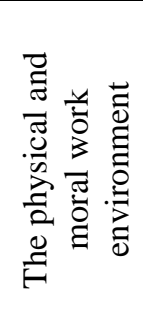 & 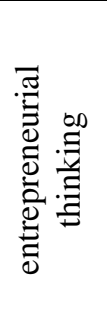 & & 0.789 & 0.779 & $\% 48.3$ & $\begin{array}{c}197.74 \\
2\end{array}$ & 0.000 & $\begin{array}{l}\text { Acceptance of the fifth } \\
\text { secondary hypothesis, } \\
\text { which documents the } \\
\text { existence of a strong moral } \\
\text { link between the physical } \\
\text { and moral work } \\
\text { environment and } \\
\text { entrepreneurial thinking }\end{array}$ \\
\hline $2-6$ & 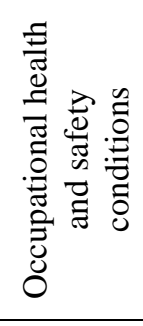 & 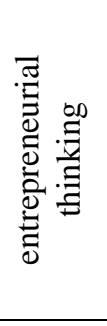 & & 0.806 & 0.781 & $\% 52.7$ & $\begin{array}{c}236.64 \\
3\end{array}$ & $\mathbf{0 . 0 0 0}$ & $\begin{array}{l}\text { Acceptance of the sixth } \\
\text { secondary hypothesis, } \\
\text { which documents the } \\
\text { existence of a strong moral } \\
\text { link between health } \\
\text { conditions and } \\
\text { occupational safety and } \\
\text { entrepreneurial thinking }\end{array}$ \\
\hline \multirow{2}{*}{\multicolumn{2}{|c|}{$\begin{array}{c}\text { Accepted } \\
\text { hypotheses }\end{array}$}} & \multicolumn{6}{|c|}{ Number } & \multicolumn{2}{|c|}{6 hypotheses out of 6 hypotheses } \\
\hline & & \multicolumn{6}{|c|}{ Percentage of accepted hypotheses number } & \multicolumn{2}{|r|}{$100 \%$} \\
\hline & & & & $\pi$ & 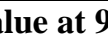 & 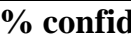 & 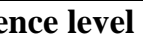 & 9201) & \\
\hline
\end{tabular}


Source: The results of the electronic calculator according to the data of the SPSS v.25 program.

Table 8: Results of the second main hypothesis test

\begin{tabular}{|c|c|c|c|c|c|c|c|c|c|}
\hline \multirow[b]{2}{*}{ 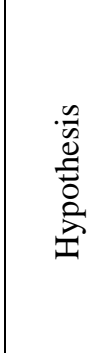 } & \multicolumn{2}{|c|}{ Variables } & \multirow[b]{2}{*}{ 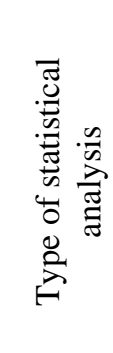 } & \multirow[b]{2}{*}{ 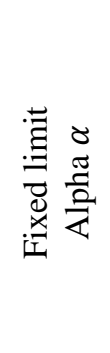 } & \multirow{2}{*}{ 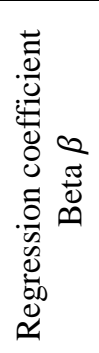 } & \multirow[b]{2}{*}{ 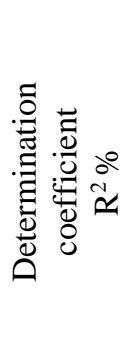 } & \multicolumn{2}{|c|}{$\begin{array}{c}\text { Statistical Lab } \\
\text { F- test }\end{array}$} & \multirow{2}{*}{ 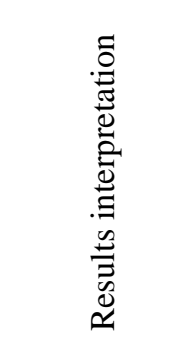 } \\
\hline & Independent & Dependent & & & & & 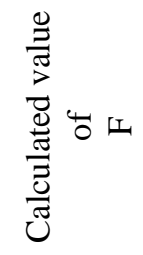 & 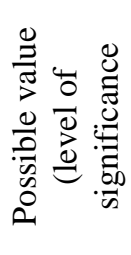 & \\
\hline \multirow{6}{*}{ 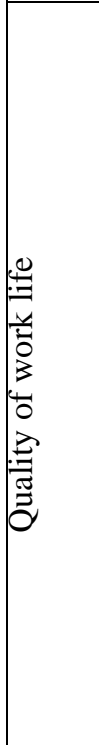 } & $\begin{array}{l}\text { Wages and } \\
\text { bonuses }\end{array}$ & $\begin{array}{l}\text { entrepreneuri } \\
\text { al thinking }\end{array}$ & \multirow{6}{*}{ 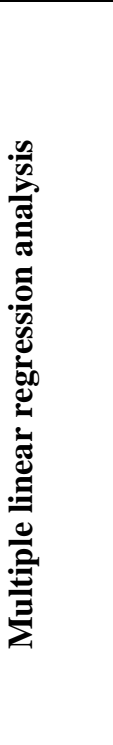 } & \multirow{6}{*}{0.094} & 0.13 & \multirow{6}{*}{$74.4 \%$} & \multirow{6}{*}{100.461} & \multirow{6}{*}{0.000} & \multirow{6}{*}{$\begin{array}{r}\text { Admittance } \\
\text { of the } \\
\text { second } \\
\text { main } \\
\text { hypothesis } \\
\text { with } 95 \% \\
\text { trust } \\
\text { meaning } \\
\text { that there is } \\
\text { a significant } \\
\text { impact on } \\
\text { the (QWL) } \\
\text { in all of its } \\
\text { six } \\
\text { dimensions } \\
\text { combined in } \\
\text { entrepreneu } \\
\text { rial thinking }\end{array}$} \\
\hline & $\begin{array}{c}\text { Organizational } \\
\text { climate }\end{array}$ & $\begin{array}{l}\text { entrepreneuri } \\
\text { al thinking }\end{array}$ & & & 0.25 & & & & \\
\hline & $\begin{array}{l}\text { Staff training } \\
\text { and } \\
\text { development }\end{array}$ & $\begin{array}{l}\text { entrepreneuri } \\
\text { al thinking }\end{array}$ & & & 0.21 & & & & \\
\hline & $\begin{array}{l}\text { Opportunities } \\
\text { for promotion } \\
\text { and career } \\
\text { advancement }\end{array}$ & $\begin{array}{l}\text { entrepreneuri } \\
\text { al thinking }\end{array}$ & & & 0.15 & & & & \\
\hline & $\begin{array}{c}\text { The material \& } \\
\text { moral work } \\
\text { environment }\end{array}$ & $\begin{array}{l}\text { entrepreneuri } \\
\text { al thinking }\end{array}$ & & & 0.15 & & & & \\
\hline & $\begin{array}{l}\text { Occupational } \\
\text { health \& safety } \\
\text { status }\end{array}$ & $\begin{array}{l}\text { entrepreneuri } \\
\text { al thinking }\end{array}$ & & & 0.16 & & & & \\
\hline
\end{tabular}

Source: The results of the electronic calculator according to the data of the SPSS v.25 program.

\section{Results of Stepwise Multiple Linear Regression to diagnose dimensions of the most influential variables in entrepreneurial thinking}

The study in this research presents the results of the statistical laboratory related to diagnosing the dimensions of the (QWL) the most influential in entrepreneurial thinking among (wages and rewards, organizational climate, training and development of workers, opportunities for promotion \& career advancement, the material and moral work environment, health conditions and occupational safety). Using the method of progressive multiple linear regression [11], which indicates the importance of each dimension of the quality of work life separately in terms of contributing to the mathematical model that reflects the effect of the (QWL) in entrepreneurial thinking, as this statistical method is considered one of the best advanced statistical methods to reach the best multiple linear regression model expressing entrepreneurial thinking in terms of quality of work life, with the necessity to note that this does not mean that the other dimensions that do not appear in the final model have no effect on entrepreneurial thinking, but their impact is less than the dimensions that it will appear in the model within the results of the progressive multiple linear regression analysis, especially since the method of progressive multiple linear regression analysis passes through several steps:

1)Building a linear correlation matrix for all variables with their dimensions, 2) We choose the dimension with the strongest correlation coefficient for it with the dependent variable and insert it into the equation (model) of gradual linear regression first, 3) Then diagnose the second dimension that has the largest correlation strength with the dimension that the model entered before it First, we examine whether there is a significant correlation between it and the dimension that was chosen before it. If the answer is yes, that dimension is excluded from the model, and on the contrary, the second dimension that will enter into the equation (model) linear regression will be gradual multiplicity, 4) The third step is repeated with the rest of the dimensions of the independent with Excluding dimensions that have a large correlation with the dimensions entering the model before it and so on, 5) the process of adding dimensions to the model becomes feasible if there is an effect of increasing the value of the coefficient of determination R2\% as well as the significant result of the F-Test, 6) we stop adding in the event the addition had no effect on the increase of the coefficient of determination R2\% and the calculated $F$ value. 
Table 9 presents the order of admission (wages and bonuses, organizational climate, employee training and development, chance for promotion and professional advancement, material and moral labor environment, health conditions \& occupational) in the multiple progressive linear regression equation. We infer that the organizational climate dimension constituted the most influential dimension in Entrepreneurial thinking, the first dimension of the quality of work life that entered into the equation of progressive multiple linear regression of entrepreneurial thinking, followed by the dimension of employee training and development to be the second dimension of the (QWL) that entered into the equation, followed by the dimension of promotion opportunities and career advancement, the third dimensions of work life quality that entered into the equation As for the health conditions and occupational safety dimension, it was the last entry into the multiple linear progressive regression equation for entrepreneurial thinking, while the analysis excluded both the wages and rewards dimension and the material and moral work environment dimension from the proposed linear model because they are less influential in entrepreneurial thinking according to the opinions of the sample.

Table 9: Outcome of the progressive regression analysis expressing entrepreneurial thinking through the (QWL) dimensions

\begin{tabular}{|c|c|c|c|c|c|c|c|c|}
\hline \multirow[b]{2}{*}{ 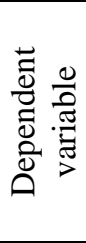 } & \multirow[b]{2}{*}{ Code } & \multirow{2}{*}{$\begin{array}{l}\text { Entrance } \\
\text { preceden } \\
\text { ce into } \\
\text { the } \\
\text { sample }\end{array}$} & \multirow{2}{*}{$\begin{array}{c}\text { Arrangement of } \\
\text { independent variable } \\
\text { dimensions entrance } \\
\text { into equation }\end{array}$} & \multirow{2}{*}{$\begin{array}{c}\text { Cod } \\
\mathrm{e}\end{array}$} & \multirow{2}{*}{$\begin{array}{c}\text { Determinatio } \\
\mathrm{n} \text { coefficient } \\
\text { for all } \\
\text { dimensions } \\
\text { entering into } \\
\text { the sample }\end{array}$} & \multicolumn{2}{|c|}{ Statistic lab F-Test } & \multirow{2}{*}{$\begin{array}{l}\text { Possibl } \\
\text { e value } \\
\text { (level } \\
\text { of } \\
\text { signific } \\
\text { ance) }\end{array}$} \\
\hline & & & & & & $\begin{array}{l}\text { Calculated } \\
\text { value of } \\
\text { F }\end{array}$ & $\begin{array}{l}\text { tabular } \\
\text { value of } \\
\text { F }\end{array}$ & \\
\hline \multirow{4}{*}{ 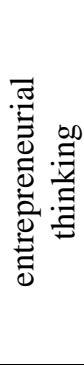 } & \multirow{4}{*}{ Y } & $1^{\text {st }}$ & $\begin{array}{r}\text { Organizational } \\
\text { climate }\end{array}$ & $\mathbf{X} 2$ & \multirow{4}{*}{$\% 72.4$} & \multirow{4}{*}{136.867} & \multirow{4}{*}{2.4472} & \multirow{4}{*}{0.000} \\
\hline & & $2^{\text {nd }}$ & $\begin{array}{r}\text { Staff training and } \\
\text { development }\end{array}$ & $\mathbf{X 3}$ & & & & \\
\hline & & $3^{\text {rd }}$ & $\begin{array}{r}\text { Opportunities for } \\
\text { promotion and career } \\
\text { advancement }\end{array}$ & X4 & & & & \\
\hline & & $4^{\text {th }}$ & $\begin{array}{l}\text { Occupational health } \\
\text { and safety conditions }\end{array}$ & X6 & & & & \\
\hline & & & $\begin{array}{l}\text { the variables include } \\
\text { thinki }\end{array}$ & & ur & & & \\
\hline
\end{tabular}

Source: The results of the electronic calculator according to the data of the SPSS v.25 program.

Displays Table (9) number of (F) calculated, which measures effect of dimensions included in the entrepreneurial thinking equation, reached (136.867), and significant for reason it is more than its tabular counterpart amounting to (2.4472), especially since the significance level was scored (0.000), which is less than level significance used in the study and amounted (0.05), brings the percentage of the impact of organizational climate dimensions, employee training and development, opportunities for promotion, career advancement, health conditions and occupational safety combined in entrepreneurial thinking to (72.4\%), as shown in figure (3) according to the data of the AMOS program. This result proves the necessity of attention by the departments of the Ministry of Labor and Social Affairs with the organizational climate, training and development of employees, chance for promotion and professional advancement, health conditions \& occupational safety when seeking to achieve entrepreneurial thinking, and thus the multiple linear regression model of the ultimate entrepreneurial thinking is as follows figure 3 :

$$
\mathrm{Y}=0.007+0.30 \times 2+0.24 \times 3+0.24 \times 4+0.23 \times 6
$$

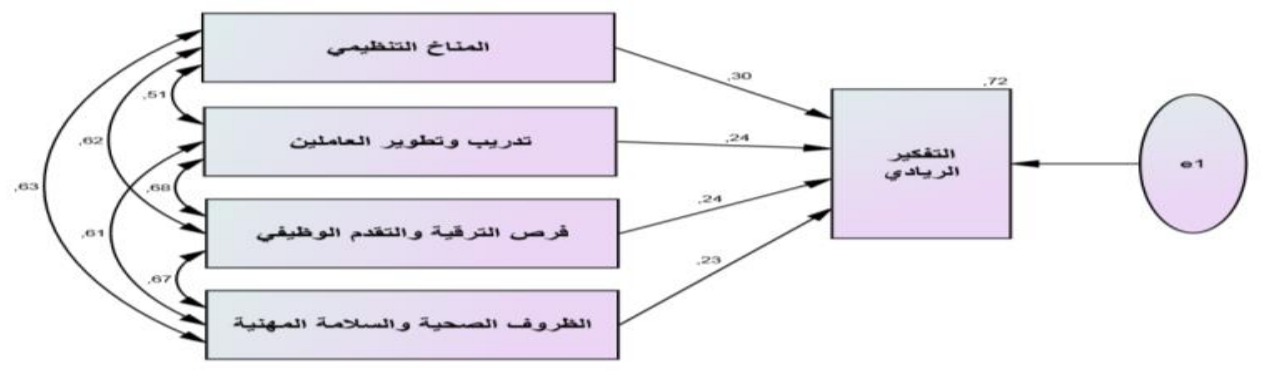

Fig 3: Results of a progressive multiple regression analysis expressing entrepreneurial thinking through the quality of work life dimensions that most affect according to the data of AMOS v.25 program 


\section{CONCLUSIONS}

The study aimed to reveal the (QWL) and its effect on entrepreneurial thinking. The study started from a problem that most service organizations suffer from weak working environment conditions for the workforce, which affected the efficiency of the employees' performance and weakness in showing their abilities and creative ideas while performing work routinely. In the surveyed ministry. Respondents agreed on most paragraphs of the (QWL) at high level, which confirms the ministry's remarkable interest in the quality of work life and its dimensions, but the nature of interest appeared in varying proportions and after the organizational climate achieved the highest level of response to confirm the agreement of most respondents that the higher management urges work within the team style to achieve the objectives of the ministry, After the wages and bonuses, the lowest level of response came to confirm that more than two-thirds of the sample members agreed on the existence of a clear and appropriate reward system in the ministry. After preemption, the highest level of response confirms that most respondents agree that management is in bodies and departments.

The Ministry is always seeking to take the initiative in the field of creating new departments and specialized units, while after the uniqueness came the lowest level of response to confirm the agreement of more than twothirds of the respondents that the researched ministry seeks to involve its employees in training courses outside the country to improve their ability to achieve quality and excellence in their field of work, There is also a strong moral correlation between the (QWL) and entrepreneurial thinking. The results of the test documented the existence of a powerful moral correlation among the organizational climate $\&$ entrepreneurial thinking at a moral level. This dimension was recorded among the dimensions of the quality of work life the highest correlation with entrepreneurial thinking, and the existence of a significant impact relationship of the organizational climate on entrepreneurial thinking was demonstrated with a determination factor of fifty-five percent. At a moral level, the test results were documented in the existence of a strong moral correlation between wages and rewards and between entrepreneurial thinking at a moral level, and this dimension among the dimensions of the QWL recorded the lowest correlation coefficient with entrepreneurial thinking, which confirms with little interest by departments in the ministry about the role of wages and bonuses, The existence of a significant impact relationship for wages and rewards in entrepreneurial thinking was also shown by the determination factor of forty-one percent at a moral level, and by multiple linear regression analysis of the six dimensions of the quality of work life combined in entrepreneurial thinking, the presence of a moral influence and an influential linear relationship with a determining factor of seventy-four percent at a moral level in the sense of a noticeable impact on the (QWL) in its six dimensions taken together in the pioneering thinking of the surveyed ministry. By diagnosing the dimensions of the most influential in entrepreneurial thinking, using progressive multiple linear regression analysis, and it came in the order of the four dimensions, which is the organizational climate. Training and development of workers, health conditions and occupational safety, promotion opportunities and career advancement combined in entrepreneurial thinking with a factor of determination of seventy-two percent at the level of significance reached less than the level of moral and excluded the dimension of wages and bonuses and dimension of the material and moral work environment, being less influenced by entrepreneurial thinking, gives remarkable attention by the departments of the ministry in the four dimensions.

\section{Recommendations}

- Drawing up employee-friendly policies by enhancing the (QWL) in the ministry's mission, including its dimensions in plans and strategies, and working to achieve them in a better way. Emphasis on the ministry's bodies and departments to work. Pay attention to the organizational climate within the team's approach to achieve the goals, and the higher management should shed light on the reward system And wages in order to achieve the quality of work life, as it was found that the rewards system is not rewarding and unsatisfactory for the efforts made by some individuals, and the financial administration must set plans in advance and link the rewards with the efficiency of the performance of the workers who deserve it, which encourages individuals to be happy in the work environment.

- The possibility of making entrepreneurial thinking a basic criterion in the ministry's regulations, especially enhancing proactiveness with constant motivation by the higher management and taking the initiative and Calculated risk for employees to present ideas and create new departments and specialized units, or evaluate ideas by reporting workers about the problems faced by the ministry in the fields of work with a demand to submit proposals for pioneering solutions, and attention to uniqueness in the availability of funding sources to work according to the vision of international companies to invest in the human mind, but the existence of a financial crisis that is still continuing requires moving to continuous education within the country to gain new knowledge and improve the ability to think pioneering and make decisions that achieve quality and value.

- When planning for the future in developing areas of work and achieving entrepreneurial thinking, the Ministry of Labor and Social Affairs should focus on the organizational climate by creating a work environment that stimulus for the optimal investment of intellectual skills for workers in the departments, for increase creativity in the field of service provision and the optimal achievement of goals And the emphasis of management on the need to pay attention to rewards and the availability of financial support for appreciation of ideas. 
- The ministry must relies in its philosophy on the six dimensions of the (QWL), which have a clear impact when it seeks to achieve entrepreneurial thinking, and it is found through diagnosing that the four dimensions have an impact in entrepreneurial thinking on the arrangement the organizational climate, training and development of workers, health conditions and occupational safety, opportunities for promotion and career advancement. and we stress the need to increase attention to wages, bonuses, and the material and moral work environment, in order to increase their influential role in achieving entrepreneurial thinking.

\section{References}

[1]. D. Jones, "A practical weight sensitivity algorithm for goal and multiple objective programming", Eur. J. Oper. Res., vol. 213, no. 1, pp. 238-245, Aug. 2011

[2]. D. Kannan, R. Khodaverdi, L. Olfat, A. Jafarian and A. Diabat, "Integrated fuzzy multi criteria decision making method and multiobjective programming approach for supplier selection and order allocation in a green supply chain", J. Cleaner Prod., vol. 47, pp. 355-367, May 2013.

[3]. L. Li, F. Liu and C. B. Li, "Customer satisfaction evaluation method for customized product development using entropy weight and analytic hierarchy process", Comput. Ind. Eng., vol. 77, pp. 80-87, Nov. 2014.

[4]. L. He, W. Song, Z. Wu, Z. Xu, M. Zheng and X. Ming, "Quantification and integration of an improved Kano model into QFD based on multi-population adaptive genetic algorithm", Comput. Ind. Eng., vol. 114, pp. 183-194, Dec. 2017.

[5]. Y.-L. Li, J.-F. Tang, K.-S. Chin, X.-G. Luo, Y. Pu and Y.-S. Jiang, "On integrating multiple type preferences into competitive analyses of customer requirements in product planning", Int. J. Prod. Econ., vol. 139, no. 1, pp. 168-179, Sep. 2012.

[6]. M. S. Cherif, H. Chabchoub and B. Aouni, "Integrating customer's preferences in the QFD planning process using a combined benchmarking and imprecise goal programming model", Int. Trans. Oper. Res., vol. 17, no. 1, pp. 85-102, Jan. 2010.

[7]. Y.-M. Wang and K.-S. Chin, "A linear goal programming approach to determining the relative importance weights of customer requirements in quality function deployment", Inf. Sci., vol. 181, no. 24, pp. 5523-5533, Dec. 2011.

[8]. Yamagishi, K. Seki and H. Nishimura, "Requirement analysis considering uncertain customer preference for Kansei quality of product", J. Adv. Mech. Des. Syst. Manuf., vol. 12, no. 1, pp. 1-13, 2018.

[9]. M. Barajas and B. Agard, "Selection of products based on customer preferences applying fuzzy logic", Int. J. Interact. Des. Manuf., vol. 5, no. 4, pp. 235-242, Nov. 2011.

[10]. N. Nishino, T. Takenaka, H. Koshiba and K. Kodama, "Customer preference-based optimization in selecting product/service variety", Cirp Ann., vol. 63, no. 1, pp. 421-424, 2014

[11]. Y. Chan, H. K. Lam, T. S. Dillon and S. H. Ling, "A stepwise-based fuzzy regression procedure for developing customer preference models in new product development", IEEE Trans. Fuzzy Syst., vol. 23, no. 5, pp. 1728-1745, Oct. 2015

[12]. M. M. S. Ullah and J. Tamaki, "Analysis of Kano-model-based customer needs for product development", Syst. Eng., vol. 14, no. 2, pp. 154-172, 2011

[13]. Schröder, "Herausforderungen von Industrie 4.0 für den Mittelstand", Bonn 2016.

[14]. Rajkumar, I. Lee, L. Sha and J. Stankovic, "Cyber physical systems: the next computing revolution", proceedings of the 47th ACM/IEEE symposium: Design Automation Confrence (DAC), July 2010.

[15]. S. Gideon, P. Lara and C. Balog, "Global Manufacturing Study Shows Early Signs of Adoption of Groundbreaking Machine-toData Technologies with China Leading the Way", Bangalore, May 2015.

[16]. Akkaya, P. Derler, S. Emoto and E. A. Lee, "Systems Engineering for Industrial Cyber-Physical Systems Using Aspects", proceedings of IEEE '16, vol. 104, no. 5, pp. 997-1012, March 2016.

[17]. E.A. Lee, "Cyber Physical Systems: Design Challenges", proceedings of 11th IEEE symposium: object oriented real-time distributed computing (ISORC), pp. 363-369, May 2008

[18]. T. Engelmann, C. Liedtke and H. Rohn, "Nachhaltiges Wirtschaften im Mittelstand: Möglichkeiten zur Steigerung der Ressourceneffizienz in kleinen und mittleren Unternehmen", Bonn 2013.

[19]. Y. Buckesfeld, Employer Branding: Strategie für die Steigerung der Arbeitgeberattraktivität in KMU, Hamburg:Diplomica Verlag, 2012.

[20]. V. Wohlgemuth and C. V. Lang, Konzepte Anwendungen und Entwicklungstendenzen von betrieblichen Umweltinformationssystemen (BUIS): Tagungsband zu den 6. BUISTagen am 24. und 25.04.2014 in Berlin (16. Tagung der Fachgruppe Betriebliche Umweltinformationssysteme der Gesellschaft für Informatik e.v.), 2014.

[21]. W. Kersten, "Industrie 4.0: Wie intelligente Vernetzung und kognitive Systeme unsere Arbeit verändern", Gito Berlin 2014.

[22]. E. Geisberger and M. Broy, "Living in a networked world: Integrated research agenda Cyber-Physical Systems (agendaCPS)" in Herbert Utz Verlag München 2015.

[23]. Schleipen, "Glossar Industrie 4.0 des Fachausschuss VDI/VDE-GMA 7.21 Industrie 4.0", Frauenhofer IOSB 2015.

[24]. V. Stich, M. Deindl, F. Jordan, L. Maecker and F. Weber, "Studie-Cyber physial Systems in der Produktionspraxis", Wuppertal 2015.

[25]. "Cyber-Physical Systems (CPS)", National Science Foundation, 2010.

[26]. F. Jordan, A. Bernardy, M. Stroh, J. Horeis and V. Stitch, "Requirements-based matching approach to configurate Cyber-Physical Systems for SMEs", proceedings of PICMET '17: International Conference on management of Engineering and Technology Technology management for interconnected world, pp. 1-7, 2017.

[27]. G. Miragliotta, A. Perego and A. Tumino, "A quantitative model for the introduction of RFID in the fast moving consumer goods supply chain: Are there any profits?", International Journal of Operations \& Production Management, vol. 29, no. 10, pp. 10491082, October 2009.

[28]. Broy, M. V. Cengarle and E. Geisberger, "Cyber-physical systems: imminent challenges", proceedings of the 17th Monterey conference on Large-Scale Complex IT Systems: development operation and management, pp. 1-28, March 2012.

[29]. Michael and L. McCathie L, "The pros and cons of RFID in supply chain management", proceedings of '05 IEEE symposium: International Conference on Mobile Business (ICMB), July 2005.

[30]. B. Srivastava, "Radio frequency ID technology: the next revolution in SCM", Business Horizons, vol. 47, no. 6, pp. 60-68, November-December 2004. 